\title{
What Are Dyslexia and Its Effects on Teaching Language Skills?
}

\author{
Mohammad Mahdi Mobinizad \\ Payam Noor University, Dubai, UAE
}

\begin{abstract}
The world of teaching comprises of a range of miscellaneous methods, plans, strategies and techniques and it gets more complex as we consider all factors affecting this world including the age group, context, the mother tongue and mental as well as natural abilities and disabilities of the students who are being taught. My main focus in this paper is to discuss language teaching tips effective for dyslexic students that can be considered as a subcategory of SEN (Special Education Needs) students and an explanation of BPMS Hypothesis I suggested helping dyslexic students overcome their learning difficulties. I also clarify my own teaching experiences in different situations throughout this paper any probably positive or negative feedbacks I obtained via teaching.
\end{abstract}

Index Terms - teaching, dyslexia, SEN, dyslexic students, experiences, BMPS hypothesis

\section{INTRODUCTION}

Dyslexia is a major cause of reading, writing, and spelling difficulties. It is a condition that makes it difficult for a person to read and spell words correctly. Based on my own teaching experience, one to three students in each class can be considered as dyslexic students. This number may be different and it depends on the total number of students present in each class. A variety of strategies can help these students to become successful students. The earlier students with dyslexia are identified, the easier it is to treat their potential problems.

In addition, the observations of parents and teachers are also crucial and can lead to an early diagnosis of such group of children. Dyslexic students are very bright and frequently highly creative with extraordinary reasoning capabilities. The old saying that male students have a higher rate of dyslexia in comparison with female students is not true nowadays and has no scientific basis at all. (Moats, 2008)

\section{A. Understanding Dyslexia}

The word dyslexia originates from Greek language, and is made of following two parts:

Dys: meaning poor / difficult

Lexis: meaning word

The literal translation is "poor words" or "difficult words".

As per definition given by National Institute of Child Health and Human Development (NICHD) based in Bethesda, Maryland, this mental condition is "a specific learning disability that is neurological in origin."

Dyslexia is a specific learning disability in reading. Kids with dyslexia have trouble reading accurately and fluently. They may also have trouble with reading comprehension, spelling and writing. (The Understood Team, 2016)

According to available statistics, the National Institute of Health estimates that approximately 15 percent of the US population is affected by learning disabilities. In addition to that, the US Department of Education figures show that approximately 4.5 percent of American students receive special educational services for a reading disorder (Pastor, P. N., \& Reuben, C. A., 2008).

\section{B. Dyslexia and Brain Function}

With the advent of functional brain imaging in the early 1990 s, neurologists and researchers were able to view the brain function while people engaged in reading. The recent advent was a great help for them to actually see how the brain translates the alphabet letters into spoken sounds. Based on Noam Chomsky's theory of Universal Grammar, the human brain is naturally wired for language and human infants just need to be around other humans who speak in order to learn the language. (Shen, H. , 2013)

To get a better understanding of the said issue, we must discuss the aspects of oral and written language separately since each one has its own role in developing language in human beings.

Oral language is comprised of 4 different levels as described in the table below:

\begin{tabular}{|l|l|l|}
\hline First Level & Phonology & Made of language sound elements called phonemes. \\
\hline Second Level & Semantics & Made of vocabulary and word meanings. \\
\hline Third Level & Syntax & Made of grammatical structures. \\
\hline Fourth Level & Discourse & Made of the way sentences are connected to make meaningful communication. \\
\hline
\end{tabular}


As it is shown in the above table, the lowest level goes for phonology and the highest level belongs to discourse.

\section{Written Language}

Contrary to the oral language, the human brains are not naturally wired to read and reading skill has to be taught. Children must develop an ability to look at the printed letters and convert them into a phonetic or linguistic code. This ability is called alphabetic principle which is a missing part in students suffering from dyslexia. Unless a student can apply the alphabetic principle, the letters are nothing except meaningless squiggles on the paper.

The most significant issue that we need to keep in mind as a language teacher is that we have 44 individual phonemes in English language which can be linked together to form an unlimited combinations of words; however, the total number of English alphabet letters is limited to 26 letters only. Consequently, each letter represents more than one sound in spoken English.

The students who have phonemic awareness-which is explained in the following pages- of spoken words and their breakdown into smaller units of sounds will not encounter any reading challenges. They just link the written letters to the language sounds and then the letters begin to have meaning for the students.

\section{Speech Symptoms of Students with Dyslexia}

Speech symptoms can be one or more than one out of the many signs listed below:

$\square$ Subtle delays in speech

$\square$ Articulation difficulties (i.e. baby talk)

$\square$ Spending long time to recall or give common vocabulary

$\square$ Misheard phonemes (i.e. dropping initial or final sounds in a word)

$\square$ Substitution of phonemes (Dyslexic student may say bar for $\boldsymbol{b a t}$ )

Sound combination in multisyllabic words (Dyslexic student may say aminal for animal)

$\square$ Sounding out (The dyslexic students is unable to connect a letter such as $\boldsymbol{b}$, with the sound /b/)

$\square$ Decoding problems and unable to sound out and spell CVC words (for example, $\boldsymbol{b o g}$ - $\boldsymbol{d o g}$ )

NOTE: CVC acronym stands for Consonant-Vowel-Consonant combination in which a vowel sound is surrounded by two consonant sounds on either side.

\section{E. Learning Behavior of Students with Dyslexia}

The learning behaviors can be monitored in early learning environments before school and even at school. These behaviors can be summarized as below:

$\square$ Like to listen to stories in class

$\square$ Missing story events and fail to unscramble them again

$\square$ Not interested in nursery rhymes due to lack of the ability to hear phonemes down)

$\square$ Unable to analyze directional concepts (difference between right and left) or positional concepts (such as up and

$\square$ Switching from the right hand to left hand when performing a task

$\square$ Pretending to feel ill at reading time

$\square$ Untidy or dirty handwriting

$\square$ Dropping word parts while reading a text

$\square$ Failure to do timely homework assignment within a specified timespan

$\square$ Less mature motor skills in comparison with others of the same age

NOTE: Motor skills refer to the function of muscle movements in the entire body.

\section{Methodology}

\section{Designated lesson plans for dyslexic students}

Dyslexic students have average to above-average intelligence. A lesson plan including following components can lead to a higher probability of gaining success in these students: (Flora, Sherrill B.,2008)

- Creative thinking tasks

- Imaginative class activities

- Drama or artistic activities

- Music-related assignments

- Multisensory activities

The above-mentioned components will also help them read faster. If we introduce new concepts to dyslexic students, they always express a high-level of understanding. Some of famous people with dyslexia are named in the table below: 


\begin{tabular}{|l|l|}
\hline Name & Profession \\
\hline Henry Ford & Inventor \\
\hline Thomas Edison & Inventor \\
\hline Walt Disney & Inventor \\
\hline Albert Einstein & Inventor / Scientist \\
\hline Jules Verne & Writer \\
\hline Orville and Wilbur Wright & Inventors \\
\hline
\end{tabular}

\section{Phonemic awareness and Q-chart}

The ability to put the individual sounds, or phonemes and work with them is called phonemic awareness. When teaching to lower grade students, I usually utilize the following Q-chart (i.e. Question chart) to recognize the students with potential disorders.

\begin{tabular}{|l|l|}
\hline Q 1: & Q 2: \\
\hline How many words can you rhyme with the word $\mathbf{b a g} ?$ & $\begin{array}{l}\text { What word do you hear when you put the sounds/b//i//g/ } \\
\text { together? }\end{array}$ \\
\hline Q 3: & Q 4: \\
\hline What is the final sound in the word tap? & $\begin{array}{l}\text { What word would you have if } / \boldsymbol{p} / \text { was taken away from the } \\
\text { word pit? }\end{array}$ \\
\hline
\end{tabular}

\section{Student status chart}

In this phase, try to scrutinize the answers you received from the students and compare them to the chart below in order to pinpoint the students' problems.

\begin{tabular}{|l|l|}
\hline Number of correct answers & Student Status \\
\hline 1 & $\begin{array}{l}\text { Needs immediate support. } \\
\text { (Implement all the components of BPMS Hypothesis) }\end{array}$ \\
\hline 2 & $\begin{array}{l}\text { Discuss the issue with parents and the school } \\
\text { counselor.(Implement in-school and at-home strategies to solve the } \\
\text { problem) }\end{array}$ \\
\hline 3 & $\begin{array}{l}\text { Try to find the exact weakness area of the student. ( Implement a } \\
\text { direct instruction plan for that weakness by paying attention to } \\
\text { BPMS Hypothesis and components) }\end{array}$ \\
\hline 4 & $\begin{array}{l}\text { The student is considered as an ordinary one and has difficulty in } \\
\text { learning. }\end{array}$ \\
\hline
\end{tabular}

As soon as I recognize dyslexic students who need serious support, I prepare a separate observation sheet for each of them and register my monthly observations in that student specified sheet. These observation sheets can be used in order to prepare designated lesson plans for those students.

The observation sheet can be used for SEN students as well since students with dyslexia can be defined as a subcategory of SEN students but my main paper focus is on providing tips for students suffering from dyslexia.

The term $\boldsymbol{S E N}$ refers to Special Education Needs Students and can include a broad range of both quick-witted and dyslexic students.

\section{Observation Chart Sample}

A sample of my observation sheet for each student is shown below:

\section{Student Monthly Observation Sheet}

Student's Name:

Class:

Teacher's Name: 
This observation sheet can be used as an evaluative tool by other school subject teachers to judge the student's progress within a month or even an academic year.

\section{RESULTS AND ANALYSIS}

Designated plan and criteria achievement

Based on my own observation from my own students, I prepared a designated plan for one of them suffering from dyslexia. The prepared plan is given as a sample below:

Teacher's Name: Mohammad Mahdi Mobinizad

Student's Name: Arya B.

Class: Grade 6D

\begin{tabular}{|l|l|l|}
\hline Targets to be achieved & Achievement Criteria & Possible Resources / Techniques \\
\hline I. Improving communication behavioral skills & 1. Engaging in any class program/activity & $\bullet$ Monitor and modify his progress \\
\hline II. Learning organizational and study skills & $\begin{array}{l}\text { 2. Teacher always involves him to be part of } \\
\text { his job }\end{array}$ & $\begin{array}{l}\text { Positive behavioral interventions and } \\
\text { support }\end{array}$ \\
\hline $\begin{array}{l}\text { III. Catching his concentration } \\
\text { 3. Competing an art activity with peers }\end{array}$ & $\begin{array}{l}\text { Team activities, team games and problem } \\
\text { solving session }\end{array}$ \\
\hline $\begin{array}{l}\text { IV. Following up the academic instructions at } \\
\text { his level }\end{array}$ & $\begin{array}{l}\text { 4. Self-management } \\
\text { concrete steps }\end{array}$ \\
\hline $\begin{array}{l}\text { V. Topping up the student level on English } \\
\text { skills }\end{array}$ & $\begin{array}{l}\text { 5. Listening to the teacher with } \\
\text { concentration and following up the relevant } \\
\text { instructions }\end{array}$ & $\begin{array}{l}\text { individual work in every subject and use } \\
\text { special worksheet based on his level }\end{array}$ \\
\hline
\end{tabular}

\section{Sample school rewards for dyslexic students}

Sometimes it may be necessary to provide school-based rewards as a kind of incentive for students with dyslexia. Teachers need to make sure that a child wants one of these potential incentives and will work for it before it is applied. Students should be given a menu of rewards such as the one I prepared below from which they can choose their favorite ones.

1) Talk to best friend

2) Listen to an iDevice player with headphones

3) Applaud the dyslexic student during school morning assembly and in the presence of other students

4) Increase the period for PE(i.e. Physical Education) class for the student during the week

5) Be teacher's helper / assistant

6) Be the class monitor / class president

7) Draw a picture or do other artistic activities in class time

8) See a movie / footage on the Web

9) Decorate the class notice board

10) Mark his classmates' exam papers

11) Be the class messenger to pass on the teacher's request to the principal assistant

12) Have treats in class or out of school

13) Be a candidate for the Student of the Day / Month

14) Give permission to play board games / card games in class

15) Assign a Certificate of Appreciation

16) Draw a gift for him from the grab bag (or lucky dip)

17) Give the student a special gift in the class

\section{Spelling suggestions for students with dyslexia}

Students suffering from dyslexia struggle with spelling problems throughout their lifetimes. As part of their primary and secondary education, they will be expected to take part in various spelling tasks and quizzes some of which are cited below.

\section{Spelling Bee Test:}

This is an annual quiz held in most of the countries across the globe and is world-famous one.

In order to get more information about the above test, you can pay a visit to the following website on the Net:

www.spellingbee.com

This website belongs to The E.W. Scripps Company and a variety of spelling bee samples are published on the said website.

\section{Spelling word flash cards:}

You can write a word on each card and ask the students to draw an illustration on the back of each flash card. The flash cards can be prepared manually or via computer programs. If the student has difficulty remembering part of the word marked on the card you can highlight that part in a different color or with a highlighter marker. Differing colors can help the student learn the word more easily.

Improving fluency skills in students with dyslexia

Oral reading can be a painful experience for students with dyslexia and they must never be forced to read aloud. The 
best time to encourage a dyslexic student to read aloud is during quiet times when nobody is around except you and one of his / her parents.

Fluency improving techniques

There are some remarkable fluency skill techniques such as:

A) Participation in story telling or reader's theater activities

In storytelling, students are asked to read a piece of writing in chorus but a reader's theatre task refers to a text that has been formatted for characters to read aloud. Each student can take the role of a character in the story and read the lines for that particular character. Both of these activities bring a lot of fun to whole class including dyslexic students.

B) Beamer / Projector reading

The teacher projects the story onto a screen and the students are requested to read the story lines. The whole class can be divided into different groups with various level of reading. In this technique, the new words of the story are either circled or highlighted no matter whatever times those words are repeated throughout the text.

C) Listening to the audio CD/ DVD

Nearly all of the story books are sold with an audio CD/DVD. The audio CD/DVD will definitely motivate the students in reading and will benefit from hearing stories prepared according to their interest levels. A list of Children's Read Aloud and Poetry Book List is provided in the appendix section of this paper.

Increasing comprehension skills in students with dyslexia

We hereby discuss the major techniques involved to aid the dyslexic students to acquire a higher level of comprehension.

A) Story comics: Prepare a four-panel comic strip of any story read to the students and ask them to illustrate four significant parts of the whole story in each panel. Speech balloons can be used over each panel as well to show the actions of story characters. These panels can be copied and distributed among the class students as a fun reading handout.

B) Big version of a favorite story: Ask your students to prepare an oversized book of a story that is popular among their age group and is liked by most of their peers in other countries. Famous stories such as Wimpy Kid and Harry Potter can be typical examples of this case.

C) Map-It-out: Ask the students to prepare a T-map as given below and include details of the story in this table:

\begin{tabular}{|l|c|}
\hline Setting & Characters \\
\hline Plot \\
\hline
\end{tabular}

Setting: refers to the place the story happened.

Characters: refer to the animals or people present in the story.

Plot: refers to a brief summary of the details and events of the story.

D) Visualize and take a picture: After reading a story is over, invite the students to come to the board and illustrate the most important scene of the story on the board. As students follow the lines of the story, they usually take a picture of the story events and form mental images of the events. These mental images made in the brain are often referred to as visualizations. The students can also add captions to their illustrations on the board.

E) True or False statements: Make a two-sided card out of thick cardboard with the word $\boldsymbol{T R U E}$ written on the front side of the card and the word $\boldsymbol{F A} \boldsymbol{L S} \boldsymbol{E}$ written on the back side of the said card. Then, distribute a copy of each card among the students. Choose an excerpt of a piece of writing and write a list of True or False statements on the board. You can prepare and write your onboard statements in a table format like below:

\begin{tabular}{|l|l|l|}
\multicolumn{4}{c}{ STORY STATEMENTS TABLE } \\
\hline 1. & True $\square$ & False $\square$ \\
\hline 2. & True $\square$ & False $\square$ \\
\hline 3. & True $\square$ & False $\square$ \\
\hline 4. & True $\square$ & False $\square$ \\
\hline
\end{tabular}

Depending on the size of the selected text and the number of statements, you can expand the total number of statements. The students will respond to each statement by showing either the front or back side of the card and the two-sided card(s) can be laminated for higher durability.

Developing writing skills in students with dyslexia

Fabulous imaginations are the major key to success in dyslexic students and can be regarded as a potential asset in their writing. It is important to tell the students that writing is a two-step process. The first step comes up with "writing ideas" and the second step goes back to proofread and correct what the student has written.

Color books can be the best choice for dyslexic students who are at the beginning level. Sometimes a drawing is worth a thousand words. In the next step, the teacher can motivate the student by making use of some of the writing prompts such as those given below:

- I am the happiest student when

- My best adventure ever was

- My hero in life is

- My toys are 
- I would like to be

An overview of the writing process stages is described under the next heading of this paper.

The writing process steps via a story organizer

1. Writing: Ask students to jot down their ideas by using a story organizer in the shape of ice-cream cone, a spider web organizer, etc. whichever sounds more interesting to them. Let them choose their favorite one freely.

2. Drafting: With reference to story organizer, students can prepare the draft copy of their writing

3. Revising: Tell students to review their draft copies and make the necessary revisions. At the end of this step, remind the students of this fact that anyone reading their work should be able to understand it.

4. Editing: Have students to prepare the final draft of their writing work by paying attention to the writing mechanics including spelling, punctuation and capitalization.

5. Sharing (or Publishing): This is the final step where the whole writing process is over and the students' work are ready to be either published on the school website or posted on the class notice board.

\section{Discussions}

BPMS Hypothesis and its components

With attention to my previous research on topics related on dyslexia, its diagnosis and the effect(s) brought on language learning skills, I reached to a hypothesis that I called it BPMS Hypothesis. This BPMS Hypothesis covers all learning challenges in dyslexic students and can be used on a large scale as an appropriate solution to such group of students.

The BPMS Hypothesis I suggested is made of 4 components as per following details:

\begin{tabular}{|l|l|l|}
\hline Component Type & Component Definition & Target Zone \\
\hline B & Backward reading & Reading \\
\hline P & Phonics booster & Listening( and spelling) \\
\hline M & Mnemonic words & Speaking \\
\hline S & Scrabble game & Writing \\
\hline
\end{tabular}

We have 26 letters in alphabet but these letters represent 44 sounds in English. It means each letter represents more than one sound. Each component concentrates on one zone of language skills. Let's take a look at each component in detail.

Component Type B (Backward reading)

In this component, the students are asked to divide the word into different parts such as prefixes, base word and suffixes and are told to start reading backwards. For example, the student can read a long word such as the word civilization in three simple steps:

\section{Example Word: civilization (civil/iz/ation)}

Step No. 1: Say -ation

Step No. 2: Say -ization

Step No. 3: Say -civilization

Note: Here the word breakdown is based on the base word and any probable prefix (es) or suffix (es) that the word may carry.

In my own experience, this approach turned out to be very effective for many students holding a different level of English knowledge and language abilities and skills and it was much easier for them to memorize and recite that specified word but it is better to apply this approach for long words that are much more difficult to pronounce than one-syllable words.

Component Type $\mathbf{P}$ (Phonics booster)

Phonics is a method of teaching people to read in which they are taught to recognize the sounds that English letters represent. Start assigning activities with one syllable words and then expand it to the longer and more complex words.

Any of the one-syllable words such as cat, bat, pat, pet, etc. can be suitable to be chosen as first choice words. Try to make a ruler-shaped box out of thick cardboard and buy or prepare at least three packs of English alphabet flash cards. The need for three series seems to be more tangible whenever you start teaching more than one syllable word at the same time.

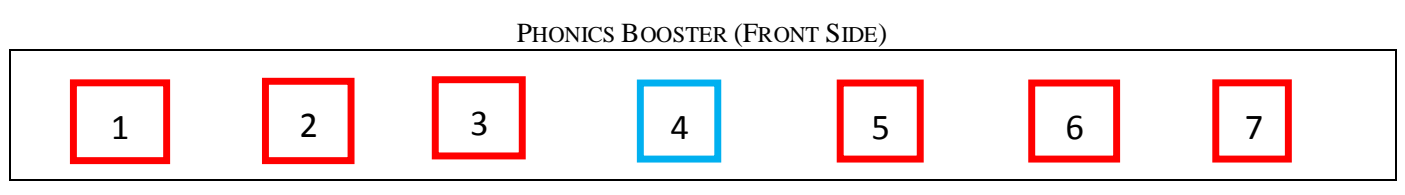

Cut out 7 squares on the front side of your ruler-shaped box and leave a distance of $1.5 \mathrm{~cm}$ between adjacent squares. Finally, assign a number to each square. The total number of the squares must not exceed seven. Cut a narrow opening on the top of each square and along the ruler-shaped box. So that you can slide the alphabet letter flash cards inwards or outwards via the top narrow opening. Most of one-syllable words are made of three English letters. Leave square No. 4 
empty and start teaching two words simultaneously in squares1-2-3 and squares 5-6-7. You can divide the whole class into 2 groups of students and teach the new words to both groups and then ask each group to read the word assigned for another group and vice versa.

The back side of your ruler-shaped box is shown below. It must exclude any cutouts.

PHONICS BOOSTER (BACK SIDE)

Phonics Booster

If you like, you can also mark the Phonics Booster on the back side of the said box you prepared in advance.

Component Type M (Mnemonic words)

This component assists both dyslexic students and ordinary students to form an individual acronym of either long phrases or words and encode those phrases or words in their mind. When there is a must to retrieve those chunks of information, the students can locate and decode the required data previously kept in their memory more easily. In this example, the chunks of information are same as the beads in a rosary that are linked together by a string and the mnemonic word here plays the same vital role of a string which keeps all the information together and in one place.

See the following examples:

What: Who has a treat?

Was: Wally ate spaghetti.

Component Type S (Scrabble game)

Scrabble is a kind of board game in which players try to make words from the separate letters they have been given. Although dyslexic students are creative thinkers, this board game can encourage the students to overcome the writing problems they may face at the preliminary stages of the writing process or afterwards.

In the long-run, this board game along with other supplementary components of BPMS Hypothesis will increase the students' interest in writing and will successfully control their prior fear or doubts that had prevented them from achieving desired results in their writing tasks. The statistical community I chose to try the effectiveness of my Hypothesis consisted of a total number of 500 hundred students in both primary and secondary school of Towheed International School in Dubai where I have gained a great deal of teaching experiences since three years ago up to the moment.

I gathered all the information I needed to verify my Hypothesis based on the student's monthly observation sheet which I provided a copy of that earlier in this paper. In order to scrutinize and analyze the results gained, I also sought for the professional advice of the school counselor.

\section{CONCLUSION}

In the end, The BPMS Hypothesis seemed to have solved the problem of almost the majority of the students involved in this project. The dyslexia will affect the learning behavior, speaking, reading, spelling and writing skills of the students suffering from this special condition and tips introduced in this appear along with BPMS Hypothesis will be effective for both the teachers and parents to help the dyslexic students tackle the challenges or difficulties they encounter in some or all of their language learning process.

\section{APPENDiX. (ChILdREN’s ReAd Aloud AND POETRy BoOK List)}

- Wells, Rosemary. (2000). Bunny Cakes. London: Puffin Books.

- Wells, Rosemary. (2000). Bunny Money. London: Puffin Books.

- Dunrea, Oliver. (1990). Eppie M. Says. New York: Simon \& Schuster.

- Donneberg, Julie. (2000). First Day Jitters. Watertown: Charlesbridge Publishing.

- Cantor, Dorothy. (2000). I Do Not Want to Get Up Today. New York: Little Brown and Company.

- Dahl, Roald. (2000). James and the Giant Peach. London: Puffin Books.

- Willems, Mo. (2004). Knuffle Bunny: A Cautionary Tale. New York: Hyperion.

- Rosenthal, Amy Krouse. (2005). Little Pea. Amy Krouse Rosenthal. San Francisco: Chronicle Books.

- Cooney, Barbara. (1982). Miss Rumphius. New York: Viking.

- Bunting, Eve. (2000). My Memory String. New York: Clarion Books.

- Angelou, Maya. (2003). My Painted House, My Friendly Chicken, and Me. San Diego: Crown Books.

- Shannon, David. (1998). No, David! New York: Scholastic Publishing.

- Falconer, Jan. (2000). Olivia. New York: Atheneum Books.

- Marzollo, Jean. (1999). Once Upon a Springtime. Minneapolis: Econo-clad Books.

- Dahl, Roald. (2000). The Enormous Crocodile. New York: Knopf Books.

- Brett, Jan. (1994). Town Mouse, Country Mouse. New York: Putnam.

- Hong, Lily Toy. (1992). Two of Everything. Park Ridge: Albert Whitman \& Company.

- Allsburg, Chris Van. (1985). The Polar Express. Boston: Houghton Mifflin Harcourt.

- Marshall, James. (1996). The Three Little Pigs. London: Puffin Books.

- Brown, Ruth. (1991). The World That Jack Built. New York: Dutton Books. 
- Long, Melinda. (2003). What Do You Do with a Tail Like This? Boston: Houghton Mifflin Harcourt

\section{REFERENCES}

[1] American Speech-Language-Hearing Association. Language-Based Learning Disabilities( Reading, Spelling, and Writing) Available at: http://www.asha.org/public/speech/disorders/LBLD/. Accessed 6 June 2010.

[2] Davis, Ronald D. (2010, February 23). The Gift of Dyslexia. New York: Perigee Trade.

[3] Department of Education. (2010). Twenty-ninth annual report to congress on the implementation of the Individuals with Disabilities Education Act, Parts B and C. 2007. Retrieved June 12, 2012, from http://www2.ed.gov/about/reports/annual/osep/2007/parts-b-c/.

[4] Flora, Sherrill B. (2008, December 19). Teaching Tips for kids with dyslexia. Minneapolis: Key Education Publishing.

[5] Moats, Louisa Cook. (2008, December). Spelling and Dyslexia. Retrieved from http://www.readingrockets.org/article/spelling-and-dyslexia.

[6] Pastor, P. N., \& Reuben, C. A. (2008). Diagnosed attention deficit hyperactivity disorder and learning disability: United States, 2004-2006. Vital and Health Statistics, 10. Retrieved June 26, 2012, from http://www.cdc.gov/nchs/data/series/sr_10/Sr10_237.pdf.

[7] The Understood Team. (2016, December 15). Understanding Dyslexia. Retrieved from https://www.understood.org/en/learning-attention-issues/child-learning-disabilities/dyslexia/understanding-dyslexia.

[8] Shen, Helen (December 5, 2013) Dyslexia Linked to Brain Communication Breakdown. Retrieved from http://www.scientificamerican.com/article/dyslexia-linked-to-brain-communication-breakdown/.

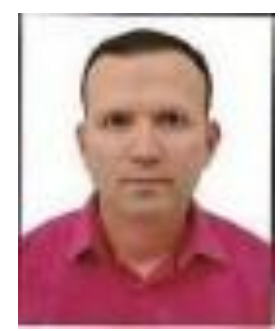

Mohammad Mahdi Mobinizad was born in Mashhad City, Iran on 27th of May, 1983. He has a BA degree in English language translation from Payame Noor University in Mashhad, Khorasane-e-Razavi Province, Iran. He also holds an MA degree in English language teaching from Payame Noor University in Dubai, UAE. He finished his undergraduate degree in 2005 and his postgraduate degree in 2017.

He has a six-year background experience as a SALES MANAGER in Maqsad International General Trading LLC in Dubai, UAE. He is currently an ENGLISH LANGUAGE, LITERATURE AND IELTS TEACHER in Towheed Iranian School in Dubai with a background experience of 5 years in Teaching English. He has also conducted a research on "The use of mobile technology in learning English language on Iranian students" that he presented the said paper in the First International Conference on New Trends in English Language Teaching and Testing in Dubai, UAE on August 24th,2017.

$\mathrm{He}$ is currently a member of International Association of Teachers of English as a Foreign Language and his IATEFL Member ID is 30941 . 